\title{
Regional Banks in the System of Government Regulation of Economy
}

Bagautdinova N.G.a

Sabitov N.H. b

Salakhov B.R.c1

Shakhnina I.Z. d

a bc d Kazan Federal University, Kazan, 420008, Russia

${ }^{1}$ Email address: verkbund@gmail.com

Doi:10.5901/mjss.2014.v5n12p39

\begin{abstract}
The article analyses activities of regional bank which is interpreted as the commercial organization which functions as a part of the banking system under the control of the central bank and takes part in the system of monetary regulation of regional economy. Special attention is paid to the mechanism of interaction and interconnection of regional bank with participants of two-level banking system which is presented by horizontal connections and relations with the other elements of the banking system and market entities in the whole, as well as by vertical connections with the central bank presented by management of banking regulation and supervisory control. Influence of macroeconomic factors on condition of the banking system is shown.
\end{abstract}

Keywords: regional bank, monetary policy, Central Bank of the Russian Federation, regional economy, monetary supply, Reserve Requirements, refinancing rate, open market transactions, credit resources.

\section{Introduction}

Inclusion of available in the region investment and financial and credit resources into economic turnover is one of conditions of solution of the problem of optimization of the structure of national economy and economy of regions. At that instruments of monetary policy of the central bank, in addition to their initial focus on monetary supply control, are aimed at encouragement of activities of institutions of financial intermediation in the direction of saturation of the real economic sector by long-term investment resources which are able to provide diversification of production $[1,4,15]$.

Being the most important instrument of state influence on regional economic behavior, economic policy of the region includes set of measures for implementation of unified state monetary policy on the local level developed by the central bank of the country.

Generated in the region monetary supply in the process of its constant flow provides provision and spending of monetary income of enterprises and population in cash and non-cash forms. On the territory of Russia money supply is distributed countrywide rather unequally concerning its size and structure. In some regions money supply has strong concentration, in other regions it's rather low. In this connection it's necessary to say that diversification of economic structure of the region as one of the strategic tasks, economic strength empowerment greatly depend on actions of money authority of the country; in particular, how greatly monetary policy of the central bank and its instruments are aimed at optimization of money supply in the country, at development and strengthening of the regional banking which allows to transform of temporarily free cash flow into long-term credits and investments.

In conditions of market exchange development of economic structure determined by actions of regional banks bearers of credit resources $[2,6]$. They - as the system-forming element of regional banking system - are the main link of impulse transmission from the sphere of monetary policy into real economic sector. At the same time commercial banks are initially affected by monetary instruments of the central bank and act as objectively important part in the mechanism of monetary economic control. Achievement of the goals of the central bank monetary policy for formation of corresponding money supply, decline in inflation, as well as condition of investment process and, as a consequence, changes towards economic structure optimization, depends on stable and efficient work of the system of banking mediation in the regions. 


\section{Methodology}

Concerning connection to mechanism of monetary regulation, regional banks were not analyzed by Russian economists thoroughly and completely. There is no definition to the word "regional bank" in modern economic dictionaries and encyclopedias. This term has not been reflected in paradigm of functioning of the Russian banking system and work of the mechanism of monetary regulation yet, it is not considered as the generally recognized category, while in other countries activities of these credit institutions is the objective of careful attention of specialists and legislative regulation. For example, in the law of the USA "In the Federal Reserve" regional banks are interpreted as specific credit institutions, as banks of the Federal Reserve in the context of their involvement in the structure of the Federal Reserve System. 12 issuing regional banks form the basis of monetary sphere of the USA.

In our country the term "regional bank" is used rather often in practice of banking activities. But, in spite of common use of this term and significance of question of founding and functioning of banks in the frames of the national banking system, there is still no legal confirmation of the status "regional bank" in documents of normative or strategic character. All this shows that questions of efficient functioning of regional banks, determining their value and role in solving question of production diversification and of social-economic development in whole should be considered as questions of special importance.

Review of the sources concerning definitions of commercial bank allows to tome to conclusion that rather often researchers don't touch such essential characteristic of its activities as performing the function of impulse transmission issued by the central bank by using definite instruments of monetary regulation, into the real economic sector $[5 ; 8 ; 11]$.

To explain one's position in this question, it's necessary, first of all, to say that, in contrast to the central bank which acts as the institution developing monetary policy, using its instruments in practice and being historically responsible to the society for stability of money supply, regional bank is commercial enterprise whose activities is a priori aimed at making profit. Thus, the question is about business nature of banking activities. This fact determines formation of stable connections of credit organization with subjects of market sphere, from one side, and with the central bank as their activities moderator, from another side. Giving in this connection the essential characteristics to the regional bank, it's necessary to say that - unlike the central bank - it is the business institution. That's why we think that it is not possible to interpret the regional bank as "office", which often occurs in domestic scientific literature. For example, even in the program of the Association of the Russian banks "National Russian banking system 2010-2020" a bank is interpreted as an office [1].

\section{Result}

In market economy the essence of a regional bank is manifested through its interaction and interconnections with participants of two-level banking system. Its horizontal ties and relations with the other elements of the banking system and commercial entities in whole are determined by unconditional commercialization of activities of all participants of the second level. Vertical ties of a regional bank are set up on the basis of dependence on the central bank, the system of banking regulation and control.

The activities of the Central bank is aimed at achievement of three main tasks. The first one presupposes to provide stability of the unit of national currency in the country, and, consequently, to provide price and financial stability. Achievement of this task cannot be successful without credit organizations of the lowest level under the control the Central Bank. The second task is connected with creating conditions for steady development and strengthening of the national banking system, in which regional banks with vertical and horizontal ties are included. The third task of activities of ventral banks is based on necessity to provide efficient and steady functioning of the payment system, satisfaction of needs of regional banks, first of all, in short-term liquidity. It is evident that achievement of all the above-mentioned tasks is connected with the activities of regional commercial banks. Relationship between elements of the first and second levels of the banking system, their interdependence are manifested through performing their own functions and solving specific problems at a definite time period [7].

Functions and tasks of central banks of different countries various, diversified and they differ from the functions of regional commercial banks. For example, traditional activities of the bank of England involves performance of the triune function: "to support Integrity and Value of national currency, to keep stability of the financial system and to provide efficiency of the sphere of financial services of the UK". And the last function of this central bank is only a part - although very important one - of implementation of the first two functions. At the same time work of Bank of Japan is aimed at problem solving to support price stability and to provide stability of financial system. There is slight difference in functions and tasks of these two issuing banks: if the Bank of England performs its functions for contribution into "healthy 
economy", the Bank of Japan considers their performance as the necessary condition of economic growth. Implementation of common monetary policy of Eurozone in the European system of central banks is one of the most important tasks of the Bank of France. The other tasks are the following: monetary policy, international relationship, issue and price support of banknotes and coins [4].

Today in conditions of production diversification necessity of shift in emphasis from retail lending by regional banks which, in the opinion of Bank of Russia, has been already approaching the dangerous line, into production financing, i.e., the real economic sector, becomes evident. The above-mentioned monetary instrument in the form of refinancing policy held by monetary instrument is of great importance for the development of these business activities of commercial bank.

Moreover, in the countries with developed banking systems the central bank affects the condition of not only monetary, but of financial market as well, by manipulations with the official bank interest rate, thus, growth of the official rate traditionally causes increase of rates of monetary operations held by regional banks on the monetary market [14. 16].

This, in its turn, determines, from one side, fall in demand for securities and corresponding, under otherwise equal conditions, increase of their supply on the stock market. At that demand for securities decreases from the side of regional non-bank organizations, as far as deposits become more attractive, as well as from the side of commercial banks, because direct financing becomes more profitable in case of tight credit. Securities offering, in its turn, increases. Thus, increase of refinancing rate determines decrease of market value of securities, their revenue position and decrease of activity of commercial banks on the stock market. Decrease of official rate, vice versa, results in easing of credits and deposits, which brings to opposite processes: demand for securities as the investment object increases, their supply decreases, their market value and revenue position increase. It results in increase of activity of regional commercial banks with securities.

In the research process the model which allows to determine the level of vulnerability of the banking sector to changes in economics, which manifests through change of return on bank assets, was worked out. The following explaining variables are included for analysis of dependence of return on assets (Table 1)

Table 1: Macroeconomic factors

\begin{tabular}{|l|l|c|}
\hline Index Name & Variable name & Assumed dependence with ROA \\
\hline GDPGR & GDP growth rates, $\%$ & Positive \\
\hline INV & Inflow(+)/outflow(-) of capital, \$ bln. & Positive \\
\hline BRENT & Oil price,\$ & Positive \\
\hline DOLLAR & Dollar rate, $\$$ & Positive \\
\hline MBK & Interbank rate of interest & Positive \\
\hline MMVB & MICEX Index & Positive \\
\hline CREDGR & Extended credits (growth rate, $\%)$ & Positive \\
\hline
\end{tabular}

Matrix of pairwise correlation on the basis of quarterly data available proves the assumed sign before explaining variables (Table 2).

Table 2: Return on assets of the banking sector - correlation coefficients

\begin{tabular}{|l|c|c|c|c|c|c|c|}
\hline & ROA & BRENT & DOLLAR & CREDGR & GDPGR & INV & SPREAD \\
\hline ROA & 1.000000 & 0.219113 & -0.380455 & 0.601095 & 0.436033 & 0.110468 & -0.282122 \\
\hline BRENT & $\mathbf{0 . 2 1 9 1 1 3}$ & 1.000000 & -0.160292 & 0.119849 & 0.308252 & 0.228311 & -0.680645 \\
\hline DOLLAR & $\mathbf{0 . 3 8 0 4 5 5}$ & -0.160292 & 1.000000 & -0.646895 & -0.143214 & -0.132998 & -0.055728 \\
\hline CREDGR & $\mathbf{0 . 6 0 1 0 9 5}$ & 0.119849 & -0.646895 & 1.000000 & 0.158972 & 0.167317 & -0.028948 \\
\hline GDPGR & $\mathbf{0 . 4 3 6 0 3 3}$ & 0.308252 & -0.143214 & 0.158972 & 1.000000 & 0.435086 & -0.313124 \\
\hline INV & $\mathbf{0 . 1 1 0 4 6 8}$ & 0.228311 & -0.132998 & 0.167317 & 0.435086 & 1.000000 & -0.268090 \\
\hline MBK & $-\mathbf{0 . 1 7 6 7 9 5}$ & -0.490089 & 0.302088 & -0.207220 & -0.300322 & -0.452261 & 0.565214 \\
\hline MMVB & $\mathbf{0 . 4 0 0 3 2 4}$ & 0.644944 & -0.471906 & 0.473593 & 0.305300 & 0.628509 & -0.599306 \\
\hline
\end{tabular}

On the basis of available data the regression dependence is set up; it explains effect of active factors on return on assets of the banking sector.

ROA $=-3.011+0.095729 *$ DOLLAR $-0.053623^{*}$ CREDGR +8.84E-05*L2GDPGR + 0.014488*L1INV + $0.00879 *$ L2INV $-0.185158 *$ L2MBK + 0.000577*MMVB

In whole, the regression is also significant, as far as $\operatorname{Prob}(f-s t)=0,000938<0,01$. Quality of fit is characterized by rather high level $R^{2}{ }^{a d j}=0,68$.

Two econometric models estimating dependence of the banking sector from dynamics of macroeconomic factors, were developed in the process of practical work. As presuppositions for the model of reserve estimate for possible losses 
let's presuppose that in the next period oil price will come down to $\$ 60$ per barrel. In the result the ruble's rate to the dollar will fall down for $20 \%$. GDP growth rates will go down for $2,9 \%$. Indicator values which are considered in the model with the account of lags, are taken from available data. Thus, initial conditions for analysis are presented in table 3.

Table 3: Analysis prerequisites

\begin{tabular}{|l|c|}
\hline INDEX & Value \\
\hline BRENT & $\$ 60 /$ barrel \\
\hline DOLLAR & 37,368 roubles \\
\hline GDPGR & $-2,9 \%$ \\
\hline L2GDPGR & 9,4587 bln. roubles \\
\hline L1INV & $-\$ 9,4$ bln. \\
\hline
\end{tabular}

We substitute these values into static and dynamic equations of dependence of reserves for possible losses from macroeconomic factors. For dynamic variants it is necessary to consider value of LLP in the previous period, its value was $-0,0534 \%$.

Static equation:

LLP $=2.836-0.006 *$ BRENT $+0.005 *$ DOLLAR $-0.0159 *$ GDPGR $-0.024 *$ L2GDPGR $-0.009 *$ L1INV

Dynamic equation:

LLP $=2.649+0.483^{\star}$ LLP1 $-0.004^{*}$ BRENT $+0.001 *$ DOLLAR $-0.013^{\star}$ GDPGR $-0.017^{\star}$ L2GDPGR $-0.006^{\star}$ L1INV

The following results were obtained in the process of substitution. Our suppositions that the above-mentioned factors negatively influence the level of credit risk expressed in dynamics of reserves for possible losses of the baking sector. Declining oil prices, the rising dollar and slowdown in GDP growth rate in conditions of the script brought to significant increase of LLP index which means necessity of increase of reserves by banks. All this, in its turn, can lead to rising costs, reduction of profit of banks and, consequently, it can threaten their financial stability. It is necessary to say that in case of the dynamic model which takes into account previous value of change of reserves, the final LLP index was lower than in the static model: 2,3\% and 2,6\% accordingly. It confirms once again that the size of reserves accumulated in the previous period, allows to smooth a little bit power of influence of macroeconomic shock.

\section{Conclusions}

Thus, our model proved that risks increase in economics negatively influences stability of the banking sector by deterioration of indices which characterize current condition of credit organizations. This fact is necessary to take into consideration while developing the policy of stability increase of banks for system risks in economics with the aim of increase of banking sector reliability and reduction of level of vulnerability for external shocks.

\section{References}

Chant, J. Financial Stability as a Policy Goal, in Essays on Financial Stability// Technical Report No. 95, Bank of Canada. - 2003.

Safiullin M.R., Samigullin I.G. and Safiullin L.N. Model of Management of Competitiveness of a Machine-building Complex// World Applied Sciences Journal, 27(13), 2013, pp. 212-216.

Ajupov A.A. Risk-Engineering, As an Element of Financial Engineering in the Market of Innovative Financial Products, 27(13), 2013, pp. 5-9.

Glebova I.S., Sadyrtdinov R. and Rodnyansky D. Impact Analysis of Investment Attractiveness of the Republic of Tatarstan on Fixed Investments of its Leading Companies // World Applied Sciences Journal 26 (7): 911-916, 2013.

Compilation Guide of Financial Soundness Indicators, Washington: International Monetary Fund. PP. 2, 185-188. URL: http://www.imf.org/external/index.htm

Crockett, A. Why is Financial Stability a Goal of Public Policy?, in Maintaining Financial Stability in a Global Economy, Symposium Proceedings, Federal Reserve Bank of Kansas City, August 1999, pp. 55-96.

Safiullin L.N., Gafurov I.R., Shaidullin R.N., Safiullin N.Z. Socio-economic development of the region and its historical and cultural heritage. Life Science Journal 2014; 11(6s): 400-404.

Gainova R.A., Shaidullin R.N., Safiullin L.N. and Maratkanova E.M. Infrastructural Component in Maintenance of Competitiveness of Region// World Applied Sciences Journal, 27(13), 2013, pp. 97-101.

Pain D. The provisioning experience of the major UK banks: a small panel investigation, Bank of England Working Paper, n. 177, London. - 2003.

Ajupov A.A., Polteva T.V. Handling depositary receipts for global financial markets. Life Science Journal 2014; 11(6s): 464 - 468.

Alpatova E.S., Makarov A.N., Maksutina E.V., Nazmeev E.F. Modern labor market in Russia and its regulation. Life Science Journal 2014; 11(6s): 350-353.

Fakhrutdinova, E., Kolesnikova, J., Yurieva, O., Kamasheva, A. The commercialization of intangible assets in the information society/l World Applied Sciences Journal. Volume 27, Issue 13, 2013, Pages 82-86.

Pesola J. "The role of macroeconomic shocks in banking crises", Bank of Finland Discussion Papers, n. 6, Helsinki. - 2001.

Quagliariello M. Banks's performance over the business cycle: a panel analysis on Italian intermediaries. The university of York, n.14. - 2007.

Zapodeanu, D., Cociuba M. (2010). Financial soundness indicators // Economics - 10(3). - 2010. 